\title{
Effect of Feeding Prepubertal Heifers with a High Oil Diet on Mammary Development and Milk Production ${ }^{1}$
}

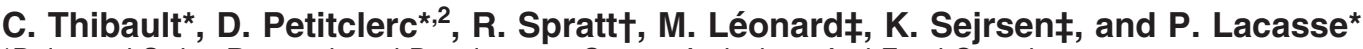 \\ *Dairy and Swine Research and Development Centre, Agriculture Agri-Food Canada, \\ P.O. Box 90, 2000 Route 108 East, Lennoxville, Quebec, J1M 1Z3, Canada \\ †Agribrands Purina Canada Inc. \\ Woodstock, Ontario, Canada \\ ‡Danish Institute of Agricultural Science \\ Foulum, Denmark
}

\begin{abstract}
The objective of this study was to evaluate the effect of feeding prepubertal heifers a diet containing a high level of polyunsaturated fatty acids on mammary development and milk production. A total of 116 Holstein heifers were either fed a conventionally formulated concentrate or a high oil (HO) concentrate, using the same formulation but including $20 \%$ soybean oil, from birth to 6 mo of age. After 6 mo of age, all heifers were managed identically. Mammary gland development was evaluated on heifers slaughtered at $4 \mathrm{mo}(\mathrm{n}=10)$ and $12 \mathrm{mo}$ $(\mathrm{n}=30)$ of age. Other heifers were bred when they reached 15 mo of age and milk production and feed intake were recorded every day from wk 4 to 18 of lactation. Feeding the high oil concentrate increased the concentration of linoleic acid in blood plasma (176\%) and mammary fat pad (78\%) at $4 \mathrm{mo}$ of age and mammary fat pad (93\%) at 12 mo of age. At 4 mo of age, mammary development was similar in both treatments. At 12 mo of age, total, parenchyma, and stroma weights of the mammary gland were not affected by treatments. However, lipid content was lower and concentration of DNA was higher in the parenchyma of heifers fed the high oil diet. Nevertheless, total parenchymal DNA and dry fat free tissue content did not reach statistical significance despite the fact that they were, respectively, 15 and $21 \%$ higher in HO heifers. Milk production and composition was not affected by treatments. In conclusion, feeding prepubertal heifers with a high oil concentrate slightly improved the mammary development but effects were too small to be translated into better lactating performances.
\end{abstract}

\footnotetext{
Received October 31, 2002.

Accepted January 21, 2003

Corresponding author: Denis Petitclerc; e-mail: denis.petitclerc@ creabiopharma.com.

${ }^{1}$ Dairy and Swine R\&D Centre contribution no. 788.

${ }^{2}$ Current address: Crea Biopharma, Inc., Place Andrew-Paton, 85 Belvedere N., Sherbrooke, Quebec, Canada J1H 4A7.
}

(Key words: mammary gland development, linoleic acid, heifers)

Abbreviation key: BrdU = 5-bromodeoxyuridine,
DFFT = dry fat free tissue, HO = high oil.

\section{INTRODUCTION}

Milk production is a function of the amount produced by each secretory cell and the number of secretory cells (Tucker, 1969; Ceriani, 1974). Therefore, factors that determine the size of epithelial cell population have also an impact on milk production. The control of mammary growth is a complex process involving many hormones as well as external influences such as photoperiod and diet. Furthermore, it has become clear that several growth stimulating or inhibiting factors, locally released under the control of the endocrine system, play a major role in the control of mammary gland development (Oka and Yoshimura, 1986; Forsyth, 1989).

The establishment of the milk yield potential of cow is critically determined during pubertal phase of mammary development (Sejrsen and Purup, 1997). At that time, the growth of the mammary gland, previously isometric, becomes allometric (Sinha and Tucker, 1969). The fat pad (mostly composed by adipocytes and connective tissue) and the ducts, formed by epithelial cells, have a rapid growth. The presence of the fat pad is essential to the parenchyma because it contributes to the growth and differentiation of epithelial cells (Cunha et al., 1995). Ducts extremities lengthen and grow into the fat pad. Well-developed and arborescent ducts will allow the development of more milk secretory cells during pregnancy. Therefore, although most of the mammary growth occurs during gestation, the duct network formation during the first year of life will determine the extent of lobulo-alveolar development.

It is well accepted that nutrition affects mammary gland development and, subsequently, milk production. The effect of nutrition appears independent of the amount (Pirlo et al., 1997) or the degradability (Mänty- 
Table 1. Composition of heifers' diet ingredients fed during the first year (DM basis).

\begin{tabular}{llccc}
\hline Parameter & $\begin{array}{l}\text { Control } \\
\text { concentrate }\end{array}$ & $\begin{array}{l}\text { High oil } \\
\text { concentrate }\end{array}$ & Hay & Grass silage \\
\hline Net energy of maintenance, Mcal/kg & & & 1.16 & 1.16 \\
Net energy of gain, Mcal/kg & & & 0.60 & 0.60 \\
ADF, \% & 14.9 & 21.1 & 38.2 & 38.1 \\
NDF, \% & 30.4 & 30.6 & 61.9 & 56.9 \\
CP, \% & 23.5 & 18.1 & 13.1 & 16.0 \\
Phosphorus, \% & 0.89 & 0.70 & 0.35 & 0.33 \\
Magnesium, \% & 0.49 & 0.39 & 0.15 & 0.19 \\
Fat, \% & 3.3 & 22.1 & & \\
\hline
\end{tabular}

saari et al. 1995; Van Amburg et al., 1998) of dietary protein or dietary energy concentration (Sejrsen and Foldager, 1991). Feeding prepubertal lambs with a supplement containing formaldehyde-protected sunflower seeds resulted in an increase of the mammary parenchyma weight (McFadden et al., 1990a). In mice, feeding diet deficient in essential fatty acids (linoleic and linolenic acids) resulted in a reduction of mammary development (Miyamoto-Tiaven et al., 1981). Several studies have shown that polyunsaturated fatty acids, linoleic acid in particular, increase mammary epithelial cells proliferation in vitro (Bandyopadhay et al., 1987). However, the impact of prepubertal diet high in linoleic acid on mammary gland development and milk production has never been evaluated in heifers.

\section{MATERIALS AND METHODS}

\section{Animals}

A first group of 72 Holstein heifers, born during winter 1997 at the Dairy and Swine R\&D Centre $(n=26)$ or bought from neighboring farms $(\mathrm{n}=46)$ was used to determine the effects of treatment on mammary gland development and, for the remaining heifers, to evaluate the impact of treatments on milk production. A second group of 44 heifers, born between mid-February and the end of August 1999 at the Centre $(n=34)$ or bought from producers $(\mathrm{n}=10)$ was used for milk production determination. Heifers were included in the project at birth for local heifers and at 2 wk of age for bought heifers. Heifers were kept in individual pens at the Research Centre from birth until $1 \mathrm{yr}$ of age under a $12 \mathrm{~h}$ of light:12 $\mathrm{h}$ of dark photoperiod.

\section{Experimental Design}

Half of the heifers were fed with a control concentrate formulated conventionally and pelleted (Table 1). The other half received high oil (HO) concentrate using the same formulation as for the control heifers but including $20 \%$ soybean oil. In order to include such a high level of oil, this concentrate was prepared by extrusion.
Fatty acid content of experimental concentrates is presented in Table 2.

At birth, heifers received colostrum then milk replacer twice a day. Timothy hay was available and concentrates were gradually introduced during the second week. Heifers were weaned when daily intake of concentrates reached $750 \mathrm{~g} / \mathrm{d}$ or at $6 \mathrm{wk}$ of age. When intake of concentrates was lower than $2.0 \mathrm{~kg} \mathrm{DM} / \mathrm{d}(1.85 \mathrm{~kg}$ $\mathrm{DM} / \mathrm{d}$ for high oil concentrate), intake of hay was limited to $1 \mathrm{~kg} / \mathrm{d}$; otherwise, hay was fed ad libitum. From 6 mo of age, hay and concentrates were gradually replaced by grass silage. Withers height and BW were recorded every 3 wk up to $1 \mathrm{yr}$ of age. Feed intake was adjusted to maintain an average BW gain of about $750 \mathrm{~g} / \mathrm{d}$.

At 4 mo of age, 10 heifers (5 per treatment) were fitted with jugular catheter and blood samples were harvested in heparin-coated tubes at $30 \mathrm{~min}$ intervals for $4 \mathrm{~h}$. These samples were used for triglyceride and fatty acids determination. From 6 mo of age, weekly blood samples were taken with heparinized vacutainer from all heifers. These plasma samples were used for progesterone determination.

Five 4-mo-old heifers per treatment were injected with $5 \mathrm{mg} / \mathrm{kg}$ BW of 5 -bromodeoxyuridine (BrdU). Seven hours later, heifers were slaughtered. The mammary gland was separated from the abdominal wall and cut along the median suspensory ligament. The left halves were stored at $-20^{\circ} \mathrm{C}$ until dissection. Samples of parenchyma (close to cisternal area), stroma and their interfaces were taken from right udder halves and

Table 2. Fatty acid contents of experimental concentrates (\% of DM).

\begin{tabular}{llc}
\hline Fatty acid & $\begin{array}{l}\text { Control } \\
\text { concentrate }\end{array}$ & $\begin{array}{l}\text { High oil } \\
\text { concentrate }\end{array}$ \\
\hline C14:0 & 0.03 & 0.04 \\
C16:0 & 0.52 & 2.43 \\
C16:1 & 0.05 & 0.04 \\
C18:0 & 0.06 & 0.98 \\
C18:1 cis 9 & 0.73 & 5.26 \\
C18:1 cis 11 & 0.07 & 0.33 \\
C18:2 & 1.68 & 11.40 \\
C18:3 & 0.17 & 1.55 \\
C20:4 & 0.02 & 0.07 \\
\hline
\end{tabular}


Table 3. Composition of heifers' diet during weeks 4 to 18 of lactation (DM basis).

\begin{tabular}{lcc}
\hline Parameter & Group $1^{1}$ & Group $2^{1}$ \\
\hline ADF, \% & 18.6 & 17.3 \\
NDF, \% & 29.3 & 29.4 \\
CP, \% & 17.7 & 18.3 \\
Phosphorus, \% & 0.62 & 0.56 \\
Magnesium, \% & 0.38 & 0.27 \\
Calcium, \% & 1.02 & 1.03 \\
\hline
\end{tabular}

${ }^{1}$ Heifers born in 1997 (group 1) or 1999 (group 2).

stored in formalin. An additional stroma sample was snap frozen in liquid nitrogen and stored at $-80^{\circ} \mathrm{C}$.

At one yr of age, 15 heifers per treatment were blocked according to BW and slaughtered in the luteal phase of the third or more oestrous cycle (determined from blood progesterone). The mammary glands were harvested and sampled similarly to those of heifers slaughtered at 4 mo of age.

Remaining heifers of the first group $(n=25)$ and those of the second group were transferred at $1 \mathrm{yr}$ of age with the rest of the Research Centre's heifers and managed according to the usual practices of the herd. All heifers were bred when they reached 15 mo of age; heifers that needed more than 3 breeding services were excluded from the trial thereafter. Three weeks before expected calving, heifers were transferred to the dairy barn and fed a transition diet. After calving, all heifers were fed a lactation diet described in Table 3. Milk production and feed intake were recorded every day from wk 4 to 18. Milk composition was determined on samples harvested once a week. Body weight and BCS were recorded weekly. Forty-four heifers (28 controls and 16 $\mathrm{HO})$ completed the lactation trial.

\section{Sample Analysis}

Fatty acids. Lipids from feed samples were extracted by the method described by Sheppard et al. (1974) and methylated with boron trifluoride (method 991.39; AOAC, 1995). Plasma lipids were extracted according to Rodriguez-Palmero (1998) with boron trifluoride. Mammary gland lipids were extracted using the method of Christie (1982) and preparation of fatty acid methyl esters was carried out as described by Chouinard et al. (1997). Fatty acid methyl ester profiles were measured by GLC as described by Delbecchi et al. (2001).

Blood parameters. Plasma triglycerides were determined using a commercial kit (Sigma Chemical Co., St. Louis, MO). Blood progesterone was determined by RIA according to Wimpy et al. (1986). A rabbit antiprogesterone antibody (Solution Recherche Inc., Ste-Foy, QC) was used at 1:12,000 dilution.
Mammary gland analysis. Frozen left udder half was sawed in $1 \mathrm{~cm}$ slices. The mammary parenchymal tissue of each slice was dissected at $4^{\circ} \mathrm{C}$ from surrounding stroma and weighed. Parenchymal tissue was ground and samples were frozen fresh or lyophilized.

Parenchyma lipid content was determined with a Soxtec HT 1043 extraction unit (Tecator ab, Höganäs, Sweden). Lyophilized parenchymal tissue was extracted twice in boiling dichloromethane and lipid content was determined from sample weight difference. Protein content of parenchyma was determined using a Kjeldahl procedure (nitrogen analyzer based on the Dumas method; LECO FP-428, Leco Corp., St. Joseph, MI, USA). DNA content was measured on fresh sampled homogenized in PBS (0.05 $M$ sodium phosphate, $2 M$ $\mathrm{NaCl}$ and $2 \mathrm{~m} M$ EDTA at $\mathrm{pH}$ 7.4) using the method described by Labarca and Paigen (1980). RNA was extracted with perchloric acid and measured by optical density at $260 \mathrm{~nm}$ (Voldin and Cahn, 1954).

\section{Histology}

Formalin-conserved tissue samples were embedded in paraffin wax and sectioned at $4 \mu \mathrm{m}$ using a microtome. From each sample, three independent slides were obtained by taking sections at $100 \mu \mathrm{m}$ intervals. Slides were stained with Mayer's haematoxylin and eosin. Individual slides were examined to obtain the histological composition of parenchymal tissue as described by Purup et al. (1993).

The effect of treatment on cell division was evaluated by BrdU labeling since BrdU is incorporated into the DNA during the S-phase of the cell cycle. Tissue sections $(4 \mu \mathrm{m})$ were cut from the paraffin blocks, mounted on microscope slides, deparaffinized and rehydrated. The mounted sections were incubated in $1 \%$ hydrogen peroxide for $20 \mathrm{~min}$ and hydrolyzed in $2 \mathrm{M} \mathrm{HCl}$ for 60 min (stopped with $0.1 \mathrm{M} \mathrm{Na}_{2} \mathrm{~B}_{4} \mathrm{O}_{7}, \mathrm{pH} 8.5$ for 5 min). The rest of the protocol for BrdU staining was developed according to the recommendations of the supplier (DAKO, Glostrup, Denmark). After demasking of the antigen by treatment with pronase (DAKO S 2013), the sections were sequentially incubated with mouse monoclonal antibody against BrdU (DAKO M 744), biotinylated rabbit anti-mouse IgG antibody (DAKO E 354) and Avidin-biotinperoxidase complex (DAKO K 0355). Nuclei staining positive for BrdU were quantified in a total of at least 1000 epithelial cells per mammary gland.

\section{Statistical Analysis}

Data were analyzed with the GLM procedure of SAS (1985). Variables repeated in time (milk production, 


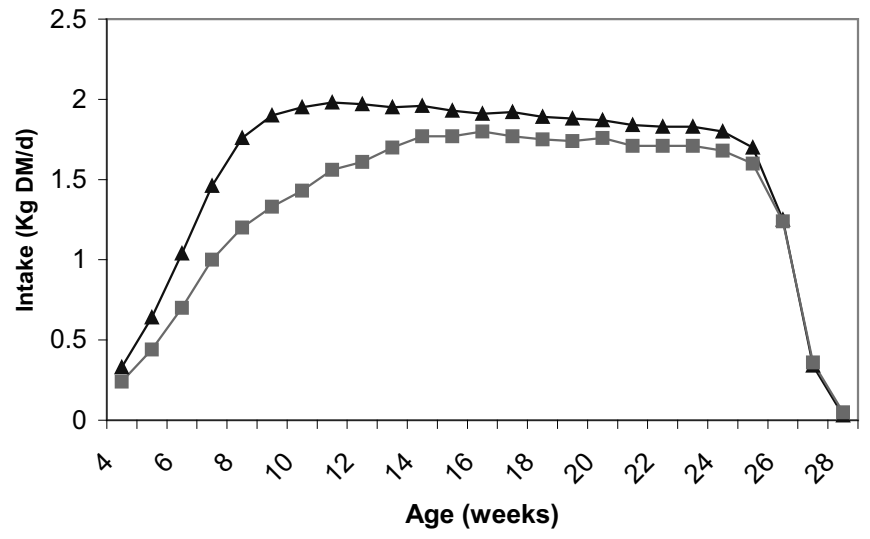

Figure 1. Intake of standard (A) or high oil ( $\mathbf{\square})$ concentrate from birth to 6 mo of age. (Standard error of least square means $\leq 0.1 \mathrm{~kg}$ ).

milk composition, DMI, and BW) were analyzed as a repeated measurement design. Age at calving was used as a covariable for milk and milk components analysis.

\section{RESULTS}

\section{Feed Intake}

The HO supplement slightly depressed feed intake $(P<0.01)$ and, therefore, it increased the time necessary to reach the maximum feed intake level allowed (2.0 and $1.85 \mathrm{~kg} \mathrm{DM} / \mathrm{d}$ for control and $\mathrm{HO}$, respectively; Figure 1). Intake of silage from 6 mo to $1 \mathrm{yr}$ of age was similar for both groups $(P>0.2$; data not shown).

\section{Growth}

Growth rate of $\mathrm{HO}$ fed heifers was slower $(P<0.05)$ during the first two months of life but was similar to the control heifers for the rest of the first year $(P>0.2$; Figure 2). During the first year of life, BW daily gains of heifers averaged 844 and $810 \mathrm{~g} / \mathrm{d}$ for control and HO, respectively. Age at first estrus was not influenced ( $P$ $>0.25$ ) by treatments, averaging 320 and $323 \mathrm{~d}$ for control and HO heifers, respectively.

\section{Blood Lipids}

Plasma concentration of triglycerides was higher $(P$ $<0.05)$ in 4-mo-old HO fed heifers than in the control heifers averaging 0.285 and $0.142 \mathrm{mmol} / \mathrm{L}$, respectively. As expected, proportion of linoleic acid in blood fatty acids increased $(P<0.001)$ from $30.5 \%$ in control to 49.9\% in HO heifers. Accordingly, proportion of C14:0, C16:0, C16:1, C18:0, cis-9 C18:1, C18:3, and C20:4 were significantly reduced in plasma fatty acids of $\mathrm{HO}$ heifers (data not shown). As blood lipids were increased in HO

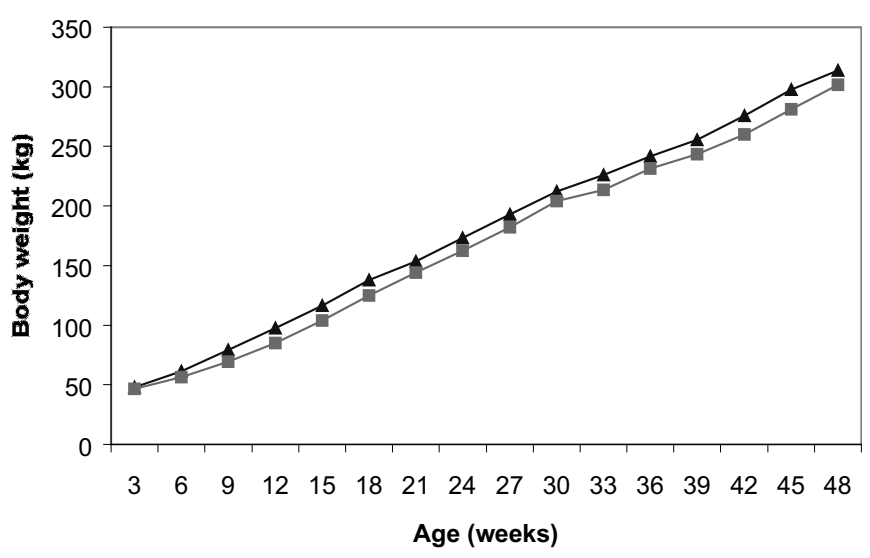

Figure 2. Body weight during the first year of life of heifers fed

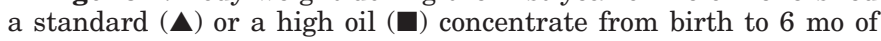
age. (Standard error of least square means $\leq 5.0 \mathrm{~kg}$ ).

heifers, concentration of linoleic acid in plasma of these heifers represented a 2.8-fold increase over that of control heifers (Table 4).

\section{Mammary Gland Development at 4 Months of Age}

Weights of the total mammary gland, parenchyma and stroma were not affected by treatments (Table 5). Similarly, chemical composition, dry fat free tissue (DFFT) and DNA content of the parenchyma were not affected (Table 6). Quantitative histological analysis shows no effect of treatments $(P>0.25)$. On average, epithelium, conjunctive tissue, adipose tissue and lumen represented 11.1, 62.0, 21.9, and $5.1 \%$ of the surface of parenchymal tissue, respectively. The proportion of epithelial cells labeled with $\mathrm{BrdU}$ was similar $(P>$ 0.2 ), averaging $5.6 \pm 0.67$ and $6.8 \pm 0.63 \%$ for control and HO heifers, respectively.

Mammary stroma fatty acid profile is presented in Table 7. Concentration of linoleic acid and trans $-\mathrm{C}_{18: 1}$ fatty acids were nearly doubled by $\mathrm{HO}$ feeding. Except

Table 4. Fatty acid concentration $(\mu \mathrm{mol} / \mathrm{l})$ in plasma of 4-mo-old heifers fed a standard (control) or a high oil concentrate from birth.

\begin{tabular}{lccll}
\hline Fatty acid & Control & High oil & SEM & $P$ \\
\hline C14:0 & 1.41 & 0.62 & 0.07 & 0.02 \\
C16:0 & 23.07 & 27.43 & 1.57 & 0.61 \\
C16:1 & 1.46 & 0.48 & 0.06 & 0.01 \\
C18:0 & 36.32 & 53.63 & 2.75 & 0.28 \\
C18:1 cis $9_{\text {C18: }}$ trans $^{1}$ & 18.33 & 15.11 & 0.99 & 0.54 \\
C18: 1 cis 11 & 5.8 & 13.4 & 0.93 & 0.14 \\
C18:2 & 1.67 & 1.11 & 0.08 & 0.22 \\
C18:3 & 43.51 & 120.21 & 4.68 & 0.01 \\
C20:4 & 5.74 & 6.99 & 0.38 & 0.47 \\
\hline
\end{tabular}

${ }^{1}$ All trans-isomers. 
Table 5. Mammary gland composition of 4-mo-old heifers fed a standard (control) or a high oil concentrate from birth.

\begin{tabular}{|c|c|c|c|c|}
\hline Parameter & Control & High oil & SEM & $P$ \\
\hline $\mathrm{BW}$ at slaughter, kg & 138.3 & 131.6 & 7.9 & 0.57 \\
\hline Weight of gland, $\mathrm{g}$ & 560.8 & 400.5 & 85.1 & 0.23 \\
\hline \multicolumn{5}{|l|}{ Parenchyma } \\
\hline weight, $\mathrm{g}$ & 51.14 & 51.61 & 7.72 & 0.97 \\
\hline$\%$ of the weight of gland & 10.08 & 12.80 & 1.61 & 0.27 \\
\hline \multicolumn{5}{|l|}{ Stroma } \\
\hline weight, $\mathrm{g}$ & 509.8 & 349.0 & 82.2 & 0.21 \\
\hline$\%$ of the weight of gland & 89.92 & 87.20 & 1.61 & 0.27 \\
\hline
\end{tabular}

Table 6. Mammary gland parenchyma composition of 4-mo-old heifers fed a standard (control) or a high oil concentrate from birth.

\begin{tabular}{lcccc}
\hline Parameter & Control & High oil & SEM & $P$ \\
\hline Fat, \% & 54.77 & 51.90 & 4.35 & 0.66 \\
Dry matter, \% & 24.44 & 24.13 & 1.90 & 0.91 \\
Protein, \% & 43.61 & 42.45 & 3.94 & 0.84 \\
DFFT, g & 2.69 & 2.79 & 0.44 & 0.88 \\
DNA, mg & 388.8 & 330.4 & 65.5 & 0.55 \\
RNA, mg & 112.1 & 127.3 & 18.2 & 0.58 \\
\hline
\end{tabular}

Table 7. Fatty acid profile (g/100 g fatty acids) of mammary stroma of 4-mo-old heifers fed a standard (control) or a high oil concentrate from birth.

\begin{tabular}{lrrll}
\hline Fatty acid & Control & High oil & SEM & $P$ \\
\hline C14:0 & 3.03 & 1.45 & 0.14 & $<0.01$ \\
C16:0 & 25.37 & 16.55 & 0.42 & $<0.01$ \\
C16:1 & 1.32 & 0.42 & 0.13 & $<0.01$ \\
C18:0 & 28.73 & 33.05 & 3.17 & 0.37 \\
C18: 1 cis 9 & 25.60 & 16.87 & 2.18 & 0.03 \\
C18: 1 trans $^{1}$ & 9.31 & 20.83 & 2.95 & 0.03 \\
C18: 1 cis 11 & 1.40 & 1.14 & 0.15 & 0.27 \\
C18:2 & 2.83 & 5.04 & 0.52 & 0.02 \\
C18:3 & 0.99 & 0.86 & 0.07 & 0.25 \\
C20:4 & 0.25 & 0.18 & 0.03 & 0.10 \\
\hline
\end{tabular}

${ }^{1}$ All trans isomers.

Table 8. Mammary gland composition of 12-mo-old heifers fed a standard (control) or a high oil concentrate from birth to 6 mo of age.

\begin{tabular}{lrrrr}
\hline Parameter & Control & High oil & SEM & $P$ \\
\hline BW at slaughter, kg & 337.1 & 335.5 & 8.0 & 0.89 \\
Weight of gland, g & 2142.6 & 1991.6 & 82.1 & 0.23 \\
Parenchyma & & & & \\
Weight, g & 487.2 & 500.4 & 36.0 & 0.80 \\
\% of the weight of gland & 23.2 & 25.7 & 1.9 & 0.36 \\
Stroma & & & & \\
Weight, g & 1655.4 & 1491.2 & 90.0 & 0.21 \\
\% of the weight of gland & 76.8 & 74.3 & 1.9 & 0.36 \\
\hline
\end{tabular}

Table 9. Mammary gland parenchyma composition of 12-mo-old heifers fed a standard (control) or a high oil concentrate from birth to 6 mo of age.

\begin{tabular}{lccrl}
\hline Parameter & Control & High oil & SEM & $P$ \\
\hline Fat, \% & 83.3 & 81.1 & 0.7 & 0.05 \\
Dry matter, \% & 49.8 & 51.9 & 1.5 & 0.35 \\
Protein, \% & 16.6 & 17.6 & 0.7 & 0.33 \\
DFFT, g & 20.3 & 24.6 & 2.3 & 0.18 \\
DNA, mg & 1739 & 2001 & 138 & 0.18 \\
RNA, mg & 570 & 636 & 30 & 0.45 \\
\hline
\end{tabular}

for stearic acid, levels of other fatty acids were unaffected or decreased by HO treatment.

\section{Mammary Gland Development at 12 Months of Age}

Weights of the total mammary gland, parenchyma and stroma were not affected by treatments (Table 8). Lipid content was lower in parenchyma from $\mathrm{HO}$ heifers (Table 9). Concentration of DNA was higher $(P<0.05)$ in the parenchyma of these heifers $(7.20$ and $8.03 \mathrm{mg}$ of DNA/g for control and HO, respectively). Nevertheless, total parenchymal DNA and DFFT content did not reach statistical significance $(P=0.18)$ despite the fact that they were, respectively, 15 and $21 \%$ higher in HO heifers.

Quantitative histological analysis shows no effect of treatments $(P>0.25)$ on epithelial cell number, which averaged $16.9 \%$ of the surface of parenchymal tissue. However, proportion of adipose tissue was higher (26.6 vs $17.5 \% ; P<0.05)$ and proportion of connective tissues was lower (52.3 vs $62.0 \% ; P<0.05$ ) in parenchyma tissue from $\mathrm{HO}$ heifers.

Despite the fact that treatments were terminated 6 mo before, mammary gland fatty acid profiles (Table 10) were consistent with those of 4-mo-old heifers. Indeed, concentration of linoleic acid and trans $-\mathrm{C}_{18: 1}$ fatty acids was also doubled by HO feeding while the levels of several other fatty acids were significantly decreased.

Table 10. Fatty acid profile ( $\mathrm{g} / 100 \mathrm{~g}$ fatty acids) of mammary stroma of 12-mo-old heifers fed a standard (control) or a high oil concentrate from birth to 6 mo of age.

\begin{tabular}{|c|c|c|c|c|}
\hline Fatty acids & Control & High oil & SEM & $P$ \\
\hline C14:0 & 3.41 & 2.95 & 0.09 & $<0.01$ \\
\hline C16:0 & 29.40 & 26.38 & 0.32 & $<0.01$ \\
\hline C16:1 & 2.88 & 1.90 & 0.20 & $<0.01$ \\
\hline C18:0 & 22.33 & 25.56 & 0.84 & 0.01 \\
\hline $\mathrm{C} 18: 1$ cis 9 & 34.54 & 29.19 & 0.72 & $<0.01$ \\
\hline C18:1 trans $^{1}$ & 4.08 & 8.83 & 0.34 & $<0.01$ \\
\hline $\mathrm{C} 18: 1 \mathrm{cis} 11$ & 0.81 & 0.85 & 0.07 & 0.73 \\
\hline C18:2 & 1.08 & 2.09 & 0.11 & $<0.01$ \\
\hline C18:3 & 0.89 & 0.94 & 0.04 & 0.41 \\
\hline C20:4 & 0.02 & 0.03 & 0.01 & 0.29 \\
\hline
\end{tabular}

${ }^{1}$ All trans-isomers. 
Table 11. Dry matter intake, milk production and milk composition of heifers fed a standard (control) or a high oil concentrate from birth to 6 mo of age. ${ }^{1}$

\begin{tabular}{lccll}
\hline Parameter & Control & High oil & SEM & $P$ \\
\hline Milk production, kg/d & 25.7 & 24.5 & 0.7 & 0.17 \\
Milk protein, \% & 3.03 & 3.06 & 0.04 & 0.66 \\
Milk protein, g/d & 779 & 746 & 0.02 & 0.17 \\
Milk fat, \% & 3.37 & 3.37 & 0.08 & 1.00 \\
Milk fat, g/d & 862 & 817 & 0.02 & 0.13 \\
Milk lactose, \% & 4.80 & 4.76 & 0.03 & 0.19 \\
\hline
\end{tabular}

${ }^{1}$ Least square means from wk 4 to wk 18 of the first lactation.

\section{Milk Production}

Average milk production in early lactation (wk 4 to wk 18) was not different among heifers subjected to the two treatments (Table 11). Content and yield of milk components were not significantly affected by feeding regime (Table 11). Body weight at calving was similar for both groups, but BW gain in early lactation was higher $(P<0.05)$ in HO than in control heifers averaging 0.14 and $0.07 \mathrm{~kg} / \mathrm{d}$, respectively. After $18 \mathrm{wk}$ of lactation, BW averaged 570 and $597 \mathrm{~kg}$ for control and HO heifers, respectively.

\section{DISCUSSION}

Adaptation of the heifers to the HO supplement was slower. The higher energetic density is not sufficient to explain the lower feed intake as a reduction of growth rate was also observed. In a previous experiment (Ouellet et al., unpublished results), we observed that daily DMI was lower for cows fed extruded concentrates (with or without fat) than a pelleted concentrate. It has been suggested that the lower density of the extruded feed may decrease ruminal degradability of starch, which in turn affects intake (Shabi et al., 1999). However, as this effect occurred well before the heifers started to ruminate, it is more likely due to a lower palatability of the supplement containing such a high level of fat than to the extrusion process itself.

The lower feed intake of $\mathrm{HO}$ heifers reduced $\mathrm{BW}$ gain during the first weeks of rearing. Rate of BW gain in prepubertal heifers has been shown to affect mammary gland development (Sejrsen et al., 1982). However, BW gain was not affected after the second month of age, well before the start of the allometric phase of mammary growth when the negative effect of high plane of nutrition is believed to occur. Therefore, it is unlikely that rate of BW gain has affected mammary growth. Nevertheless, we cannot exclude the possibility that lower rate of $\mathrm{BW}$ gain from birth to 2 mo of age may have affected mammary stem cell proliferation and, therefore, have lasting detrimental effects on mam- mary growth thereby masking the potential beneficial effects of $\mathrm{HO}$ diet.

Fatty acid profiles of blood plasma and mammary gland stroma show that the HO supplement succeeded at increasing postruminal level of linoleic acid. However, trans $-\mathrm{C}_{18: 1}$ fatty acids, which are produced during ruminal biohydrogenation of linoleic and linolenic acids (Harfoot and Hazlewood, 1988), were also increased. These changes are characteristic of a diet high in unprotected fat. Chouinard et al. (1997) fed cows raw soybeans or soybeans extruded at three different temperatures. They observed that extrusion of soybeans only slightly decreased the in situ disappearance of linoleic and linolenic acid and did not increase polyunsaturated fatty acid content of milk fat. Similarly, Bauchart et al. (1990) reported no effect of extrusion of rapeseed on rumen biohydrogenation of linoleic acid. Therefore, despite that extrusion of feedstuffs induces the formation of noncovalent interactions among proteins and lipids, which reduce lipid extractability (Izzo and Ho, 1989), the protective effect of extrusion is probably marginal. Although young heifers are considered as preruminants, a good protection of fatty acids appears to be necessary in order to increase efficiently the level of unsaturated fatty acids absorbed.

The tissue composition analyses of the mammary glands of heifers slaughtered at 4 mo show no difference in mammary development at the start of the first allometric phase. At the end of this intense period of mammary development (12 mo), the weight of the parenchyma has increased tenfold. Although all parameters of mammary development were numerically improved in HO heifers, only the lipid and DNA concentrations in parenchyma reached statistical significance. McFadden et al. (1990a) observed similar effects but at a higher magnitude when feeding prepubertal lambs with formaldehyde-protected sunflower seeds. Compared to the lambs fed a standard diet, lambs fed sunflower seeds had slightly larger udders (13\%), which contained $65 \%$ bigger parenchyma and $80 \%$ more DFFT. One possible explanation for this larger effect is the better protection offered by formaldehyde treatment compared to extrusion. In their experiments, level of linoleic acid in mammary lipids reached 11\% (McFadden et al., 1990b) compared to $5 \%$ at $4 \mathrm{mo}$ and $2 \%$ at $12 \mathrm{mo}$ of age in our experiment.

The trend for a better mammary development did not result in better lactation performances. To our knowledge, no other experiment has been carried out to evaluate the effect on milk production of feeding high-linoleic acid diet during rearing. Unfortunately, milk production and mammary development could not be measured on the same animals. However, several experiments on plane of nutrition before puberty have 
shown that, most of the time, planes of nutrition that affect mammary gland development at the end of the allometric phase also affect milk production (Little and Kay, 1979; Valentine et al., 1987; Foldager and Sejrsen, 1991). Therefore we think that the effects on mammary development were too small to be translated into better lactating performances.

\section{REFERENCES}

Association of Official Analytical Chemists. 1995. Official methods of analysis. 16th ed. AOAC International. Gaitherburg, MD.

Bandyopadhyay, G. K., W. Imagawa, D. Wallace, and S. Nandi. 1987. Linoleate metabolites enhance the in vitro proliferative response of mouse mammary epithelial cells to epidermal growth factor. J. Biol. Chem. 262:2750-2756.

Bauchart, D., F. Legay-Carmier, and M. Doreau. 1990. Relationship between intake and duodenal flows of linoleic acid in dairy cows fed lipid-supplemented diets. Reprod. Nutr. Dev. (Suppl. 2) 188s.

Ceriani, R. L. 1974. Hormones and other factors controlling growth in the mammary gland: A review. J. Invest. Derm. 63:93-108.

Chouinard P. Y., J. Lévesque, V. Girard, and G. J. Brisson. 1997 Dietary soybeans extruded at different temperatures: milk composition and in situ fatty acid reactions. J. Dairy Sci. 80:29132924.

Christie, W. W. 1982. Lipid analysis. 2nd ed. Pergamon Press. Oxford.

Cunha, G. R., P. Young, K. Cristov, R. Guzman, S. Nandi, and F. Talamantes. 1995. Mammary phenotypic expression induced in epidermal cells by embryonic mammary mesenchyme. Acta Anatomica. 152:195-204.

Delbecchi, C., E. Ahnadi, J. J. Kennelly, and P. Lacasse. 2001. Milk fatty acid composition and mammary lipid metabolism in Holstein cows fed protected or unprotected canola seeds. J. Dairy Sci. 84:1375-1381.

Foldager, J., and K. Sejrsen. 1991. Rearing intensity in dairy heifers and the effect on subsequent milk production. Report from the National Institute of Animal Science, Foulum, Denmark. No. 693.

Forsyth, I. A. 1989. Growth factors in mammary gland function. J. Reprod. Fert. 85:759-770.

Harfoot, C. G., and G. P. Hazlewood. 1988. Lipid metabolism in the rumen. Pages 285-322 in The rumen microbial ecosystem. P. N. Hobson (Ed.). Elsevier Science Publishers, London.

Izzo, M. T., and C. T. Ho. 1989. Protein-lipid interaction during singlescrew extrusion of zein and corn oil. Cereal Chem. 66:47-51.

Labarca, C., and K. Paigen. 1980. A simple, rapid, and sensitive DNA assay procedure. Anal. Biochem. 102:344-352.

Little, W., and R. M. Kay. 1979. The effects of rapid rearing and early calving on the subsequent performance of dairy heifers. Anim. Prod. 29:131-142.

Mäntysaari, P., K. L. Ingvartsen, V. Toivonen, and K. Sejrsen. 1995. The effects of feeding level and nitrogen source of the diet on mammary development and plasma hormone concentrations of pre-pubertal heifers. Acta. Agric. Scand. Sect. A. Animal Sci. $45: 236-244$
McFadden, T. B., T. E. Daniel, and R. M. Akers. 1990a. Effects of plane of nutrition, growth hormone and unsaturated fat on mammary growth in prepubertal lambs. J. Anim. Sci. 68:3171-3179.

McFadden, T. B., T. E. Daniel, and R. M. Akers. 1990b. Effect of plane of nutrition, growth hormone and unsaturated fat on growth hormone, insulin and prolactin receptors in prepubertal lambs, J. Anim. Sci. 68:3180-3189.

Miyamoto-Tiaven, M. J., L. A. Hillyard, and S. Abraham. 1981. Influence of dietary fat on the growth of mammary ducts in BALB/c Mice. J. Natl. Cancer Inst. 67:179-188.

Oka, T., and M. Yoshimura. 1986. Paracrine regulation of mammary gland growth. Clin. Endocrinol. Metab. 15:79-97.

Pirlo, G., M. Capelletti, and G. Marchetto. 1997. Effects of energy allowances in the diets of prepubertal heifers on growth and milk production. J. Dairy Sci. 80:730-739.

Purup, S., K. Sejrsen, J. Foldager, and R. M. Akers. 1993. Effects of exogenous bovine growth hormone and ovariectomy on prepubertal mammary growth, serum hormones and acute in vitro proliferative response of mammary explants from Holstein heifers. J. Endocrinol. 139:19-26.

Rodriguez-Palmero, M., M. C. Lopez-Sabater, A. I. Castellote-Bargallo, M. M. De La Torre-Boronat, and M. Rivero-Urgell. 1998. Comparison of two methods for the determination of fatty acid profiles in plasma and erythrocytes. J. Chromatogr. 793:435-440.

Sejrsen, K., and J. Foldager. 1991. Mammary growth and milk production capacity of replacement heifers in relation to diet energy concentration and plasma hormone levels. Acta. Agr. Scand. 42:99-105.

Sejrsen, K., and S. Purup. 1997. Influence of prepubertal feeding level on milk yield potential of dairy heifers: a review. J. Anim. Sci. 75:828-835.

Shabi, Z., I. Bruckental, S. Zamwell, H. Tagari, and A. Arieli. 1999. Effects of extrusion of grain and feeding frequency on rumen fermentation, nutrient digestibility, and milk yield and composition in dairy cows. J. Dairy Sci. 82:1252-1260.

Sheppard, A. J., W. D. Hubbard, and A. R. Prosser. 1974. Evaluation of eight extraction methods and their effects upon total fat and gas liquid chromatographic fatty acid composition analyses of food products. J. Am. Oil Chem. Soc. 51:416-418.

Sinha, Y. N., and H. A. Tucker. 1969. Mammary development and pituitary prolactin level of heifer from birth through puberty and during the estrous cycle. J. Dairy Sci. 52:507-512.

Statistical Analysis System Institute Inc. 1985. SAS user's guide, SAS Institute Inc. (ed.), Statistics, version 5, Cary, NC.

Tucker, H. A. 1969. Factors affecting mammary gland cell numbers. J. Dairy Sci. 52:720-729.

Valentine, S. C., R. C. Dobos, P. A. Lewis, B. D. Bartsch, and R. B. Wickes. 1987. Effect of liveweight gain before or during pregnancy on mammary gland development and subsequent milk production of Australian Holstein-Friesian heifers. Aust. J. Exp. Agric. 27:195-204.

Van Amburg, M. E., D. M. Galton, D. E. Bauman, R. W. Everett, D. G. Fox, L. E. Chase, and H. N. Erb. 1998. Effects of three prepubertal body growth rates on performance of Holstein heifers during first lactation. J. Dairy Sci. 81:527-538.

Voldin, E., and W. E. Cahn. 1954. Estimation of nucleic acids. Methods Biochem. Anal. 1:287-303.

Wimpy, T. H., C. F. Chang, V. L. Estergreen, and J. K. Hillers. 1986. Milk progesterone enzyme immunoassay: modification and field trial for pregnancy detection in dairy cows. J. Dairy Sci. 69:1115-1121. 